\title{
Clinical simulation for nursing competence development in cardiopulmonary resuscitation: systematic review
}

\author{
Juliana da Silva Garcia Nascimento $0^{1,2}$ \\ (D) https://orcid.org/0000-0003-1118-2738 \\ Kleiton Gonçalves do Nascimento ${ }^{3}$ \\ (1D) https://orcid.org/0000-0002-2717-6837 \\ Jordana Luiza Gouvêa de Oliveira ${ }^{1}$ \\ (D) https://orcid.org/0000-0001-5905-8993 \\ Mateus Goulart Alves ${ }^{4}$ \\ (D) https://orcid.org/0000-0003-0680-6817 \\ Aline Roberta da Silva ${ }^{1}$ \\ (D) https://orcid.org/0000-0001-8214-5534 \\ Maria Celia Barcellos Dalri ${ }^{1}$ \\ (D) https://orcid.org/0000-0002-8173-8642
}

Objective: to identify the effectiveness of clinical simulation for competence development regarding cardiopulmonary resuscitation in comparison with different teaching and learning strategies used in the education of nursing students. Method: systematic review, performed on the databases PubMed ${ }^{\circledR} /$ MEDLINE ${ }^{\circledR}$, LILACS, Scopus, CINAHL and Web of Science. The Rayyan QCRI application was used to select the studies, in addition to the instruments for assessing the methodological quality of Joanna Briggs Institute and the Medical Education Research Study Quality Instrument. Results: a total of 887 studies were identified, and five we included in the final sample. The included studies had good methodological quality by the assessment instruments. All of them had statistically significant results to develop competence through clinical simulation, when compared to other methods. Conclusion: clinical simulation proved to be effective for the development of clinical competence in cardiopulmonary resuscitation of nursing students.

Descriptors: Students, Nursing; Simulation Technique; Teaching; Clinical Competence; Cardiopulmonary Resuscitation; Learning.

\section{How to cite this article}

Nascimento JSG, Nascimento KG, Oliveira JLG, Alves MG, Silva AR, Dalri MCB. Clinical simulation for nursing competence development in cardiopulmonary resuscitation: systematic review. Rev. Latino-Am. Enfermagem. 2020;28:e3391. [Access ]; Available in: DOI: http://dx.doi.org/ 10.1590/1518-8345.4094.3391. 


\section{Introduction}

Adopting new teaching and learning strategies in nursing is very important for excellence in the development of students' knowledge, skills and attitudes $^{(1-2)}$. Thus, clinical simulation, configured as a pedagogical mechanism for teaching and learning in health, which imitates real clinical care, has gained space in nursing education, characterized as an experiential, interactive, collaborative and learnercentered strategy ${ }^{(3)}$.

Specifically regarding teaching and learning of cardiopulmonary resuscitation (CPR) for nursing, strategies frequently adopted by educators are still guided by traditional approaches, such as lectures supported by PowerPoint ${ }^{\circledR}$ presentations and laboratory skills training guided by an instructor ${ }^{(4-5)}$.

This classic pattern of CPR training has shown ineffective results for care quality, such as a decrease in the cognitive and psychomotor skills of individuals 1 month after the completion of the courses ${ }^{(6-7)}$. However, it is not yet clear whether new teaching and learning strategies, such as clinical simulation, are more effective in developing the competence of nursing students to attend $\mathrm{CPR}^{(4,8)}$.

The evaluation of the development of clinical competence, defined as the application of skills in all domains of practice, articulating knowledge, skills and attitudes in different clinical contexts $(7,9)$, is considered a complex and difficult to handle topic. Its use in the teaching of CPR to nursing students was verified in studies whose outcomes were varied and not always conclusive regarding its effectiveness ${ }^{(10-12)}$.

This study aimed to identify the effectiveness of clinical simulation for competence development regarding CPR in comparison with different teaching and learning strategies used in the education of nursing students.

\section{Method}

This is a systematic literature review, prepared in accordance with the Preferred Reporting Items for Systematic Reviews and Meta-Analysis (PRISMA) strategy ${ }^{(13)}$, from July to October 2019.

To comply with this systematic review, seven steps were followed: (1) definition of the research question, specifying the population and the intervention of interest; (2) identification of databases, descriptors, keywords and search strategies; (3) establishment of inclusion and exclusion criteria; (4) search databases with up to two independent researchers; (5) comparison of examiners' searches and definition of initial study selection; (6) application of the inclusion criteria and justification for possible exclusions, along with the critical analysis of all studies included in the review; (7) elaboration of a critical summary, synthesizing the information made available by the articles included in the review, and presentation of conclusion, informing the evidence on the effects of the intervention ${ }^{(14)}$.

The research question was defined through the Patient - Intervention - Comparison-Outcomes (PICO) strategy ${ }^{(15)}$ with the following elements: the acronym $\mathrm{P}$ referred to undergraduate nursing students; I, clinical simulation; C, different teaching and learning strategies; and $\mathrm{O}$, the development of clinical competence for CPR. Thus, the following guiding question was structured: What is the effectiveness of clinical simulation in comparison with different teaching and learning strategies for competence development regarding CPR in nursing students?

The following databases were defined as data source: PubMed ${ }^{\circledR} /$ MEDLINE $^{\circledR}$, Latin American and Caribbean Literature on Health Sciences (LILACS), Scopus, Cumulative Index to Nursing and Allied Health Literature (CINAHL) and Web of Science.

According to the database, specific descriptors and search strategies were used. In PubMed ${ }^{\circledR}$ and Scopus, the descriptors found in Medical Subjects Headings (MESH) "Students, Nursing", "Simulation Training", "Teaching", "Clinical Competence" and "Cardiopulmonary Resuscitation" were used, and the search strategies were P versus I - ("Students, Nursing" OR "Pupil Nurses" OR "Student, Nursing" OR "Nurses, Pupil" OR "Nurse, Pupil" OR "Pupil Nurse" OR "Nursing Student" OR "Nursing Students") AND ("Training, Simulation" OR "Interactive Learning" OR "Learning, Interactive") - and I versus C versus O - ("Training, Simulation" OR "Interactive Learning" OR "Learning, Interactive") AND (Teaching OR "Training Techniques" OR "Technique, Training" OR "Techniques, Training" OR "Training Technique" OR "Training Technics" OR "Technic, Training" OR "Technics, Training" OR "Training Technic" OR "Pedagogy" OR "Pedagogies" OR "Teaching Methods" OR "Method, Teaching" OR "Methods, Teaching" OR "Teaching Method" OR "Academic Training" OR "Training, Academic" OR "Training Activities" OR "Activities, Training" OR "Training Activity" OR "Techniques, Educational" OR "Technics, Educational" OR "Educational Technics" OR "Educational Technic" OR 
"Technic, Educational" OR "Educational Techniques" OR "Educational Technique" OR "Technique, Educational") AND ("Clinical Competence" OR "Competency, Clinical" OR "Competence, Clinical" OR "Clinical Competency" OR "Clinical Competencies" OR "Competencies, Clinical" OR "Clinical Skill" OR "Skill, Clinical" OR "Skills, Clinical" OR "Clinical Skills") AND ("Clinical Competence" OR "Competency, Clinical" OR "Competence, Clinical" OR "Clinical Competency" OR "Clinical Competencies" OR "Competencies, Clinical" OR "Clinical Skill" OR "Skill, Clinical" OR "Skills, Clinical" OR "Clinical Skills") AND ("Cardiopulmonary Resuscitation" OR "Resuscitation, Cardiopulmonary" OR CPR OR "Cardio-Pulmonary Resuscitation" OR "Cardio Pulmonary Resuscitation" OR "Resuscitation, Cardio-Pulmonary" OR "Code Blue" OR "Mouth-to-Mouth Resuscitation" OR "Mouth to Mouth Resuscitation" OR "Mouth-to-Mouth Resuscitations" OR "Resuscitation, Mouth-to-Mouth" OR "Resuscitations, Mouth-to-Mouth" OR "Basic Cardiac Life Support" OR "Life Support, Basic Cardiac").

In CINAHL, the descriptors were "Students, Nursing", "Simulations", "Teaching", "Clinical Competence" and "Resuscitation, Cardiopulmonary", identified in titles, and the following search strategies were applied: P versus I - ("Students, Nursing") AND (Simulations) - and I versus $\mathrm{C}$ versus $\mathrm{O}$ - (Simulations) AND (Teaching OR "Models, Educational") AND ("Clinical Competence") AND ("Resuscitation, Cardiopulmonary").

In Web of Science, the descriptors "Students, Nursing", "Simulation Training", "Teaching", "Clinical Competence" and "Cardiopulmonary Resuscitation" were used. The search strategy was configured as: ("Students, Nursing" AND "Simulation Training" AND Teaching AND "Clinical Competence" AND "Cardiopulmonary Resuscitation").

At LILACS, the following Health Science Descriptors (DeCS) were searched: "Nursing Students", "Simulation Training", "Teaching", "Clinical Competence", "Cardiopulmonary Resuscitation" and their English and Spanish versions, with the following search strategy: ("Students, Nursing") AND ("Simulation Training") AND (Teaching) AND ("Clinical Competence") AND ("Cardiopulmonary Resuscitation") ("Estudiantes de Enfermería") AND ("Entrenamiento Simulado") AND (Enseñanza) AND ("Competencia Clínica") AND ("Reanimación Cardiopulmonar") ("Nursing Students") AND ("Simulation Training") AND (Teaching) AND ("Clinical Competence") AND ("Cardiopulmonary Resuscitation").

Primary studies of clinical trial type, randomized or not, were included, which presented the comparison of the effectiveness of clinical simulation to develop competence on CPR in adults with other teaching and learning strategies applied to undergraduate nursing students, without delimited timeline; published in Portuguese, English and Spanish; in scientific journals and electronically available. Studies that addressed nursing professionals, neonatal and pediatric CPR, literature reviews, editorials, reviews, experience reports, case studies, theoretical reflections, dissertations, theses, monographs and summaries published in annals of events were excluded.

The studies were identified in the information sources selected by two independent researchers, previously trained to evaluate titles and abstracts, through a single version free web review program named Rayyan Qatar Computing Research Institute (Rayyan QCRI)(16), identified at the link https://rayyan. qcri.org/.

Rayyan QCRI helps authors of systematic reviews to carry out their work quickly, easily and pleasantly, allowing the export of studies from a certain database for the program and the exposure of titles and abstracts, with the blindness of the auxiliary researcher, which guarantees reliability in the selection of information, accuracy and methodological precision ${ }^{(16)}$.

The 12 studies that showed divergence were sent to a third researcher, specialized in the theme, responsible for making the decision to include or exclude, and then a critical analysis of the articles was carried out. After we observed the incipience of selected studies, the references of the included articles were analyzed, without resulting in new additions to the final sample.

In data collection, the criteria from a validated instrument(17) were used, addressing title, authors, year of publication, origin of the study, language, journal, objectives, methodological design, results and conclusion. The Evidence Level ${ }^{(18)}$ was also classified and the selection and inclusion of studies was demonstrated following the recommendations of the Preferred Reporting Items for Systematic Review and MetaAnalyzes-PRISMA ${ }^{(13)}$.

The methodological evaluation of the selected studies was carried out according to the critical evaluation instruments from Joanna Briggs Institute ${ }^{(19)}$ and Medical Education Research Study Quality Instrument (MERSQI) (20). We opted to use both to obtain a broad scenario of evaluation of the articles methodological quality, since 
the adopted instruments have different perspectives and evaluation criteria.

The instrument referring to Joanna Briggs Institute has a total of nine items of methodological evaluation aimed at quasi-experimental studies and 13 for experimental ones and considers whether they are present, absent, and whether there is clarity or not ${ }^{(19)}$. MERSQI consists of a total of six domains, composed of criteria that assess the methodological quality of the studies: (1) study design (only one group or a posttest, 1 point; pre-test and post-test of a single group, 1.5 points, two non-randomized groups, 2 points and a randomized study, 3 points); (2) sample (one studied institution, 0.5 point; two institutions, 1 point; three studied institutions, 1.5 point and the sample response rate $<50 \%, 0.5$ point; $50 \%$ to $74 \%, 1$ point and
$>75 \%, 1.5$ points); (3) data type (assessment made by the participants, 1 point and objective assessment, 2 points); (4) validity of the assessment instrument (internal structure not reported, zero point; reported, 1 point; unreported content, zero point; reported content, 1 point; relations with other unreported variables, zero point and reported relations, 1 point); (5) data analysis (inappropriate for the study design or data type, zero point; appropriate for the study design, 1 point; only descriptive analysis, 1 point; in addition to descriptive analysis, 2 points); and (6) results (obtaining knowledge and skills, 1.5 points; satisfaction, attitudes, perceptions, opinions, general facts and confidence, 1 point). The maximum score is $18^{(20)}$. Studies with scores $\leq 10$ are considered low quality ones; from $>10$ to $<15$, moderate quality; and $\geq 15$, high quality(21).

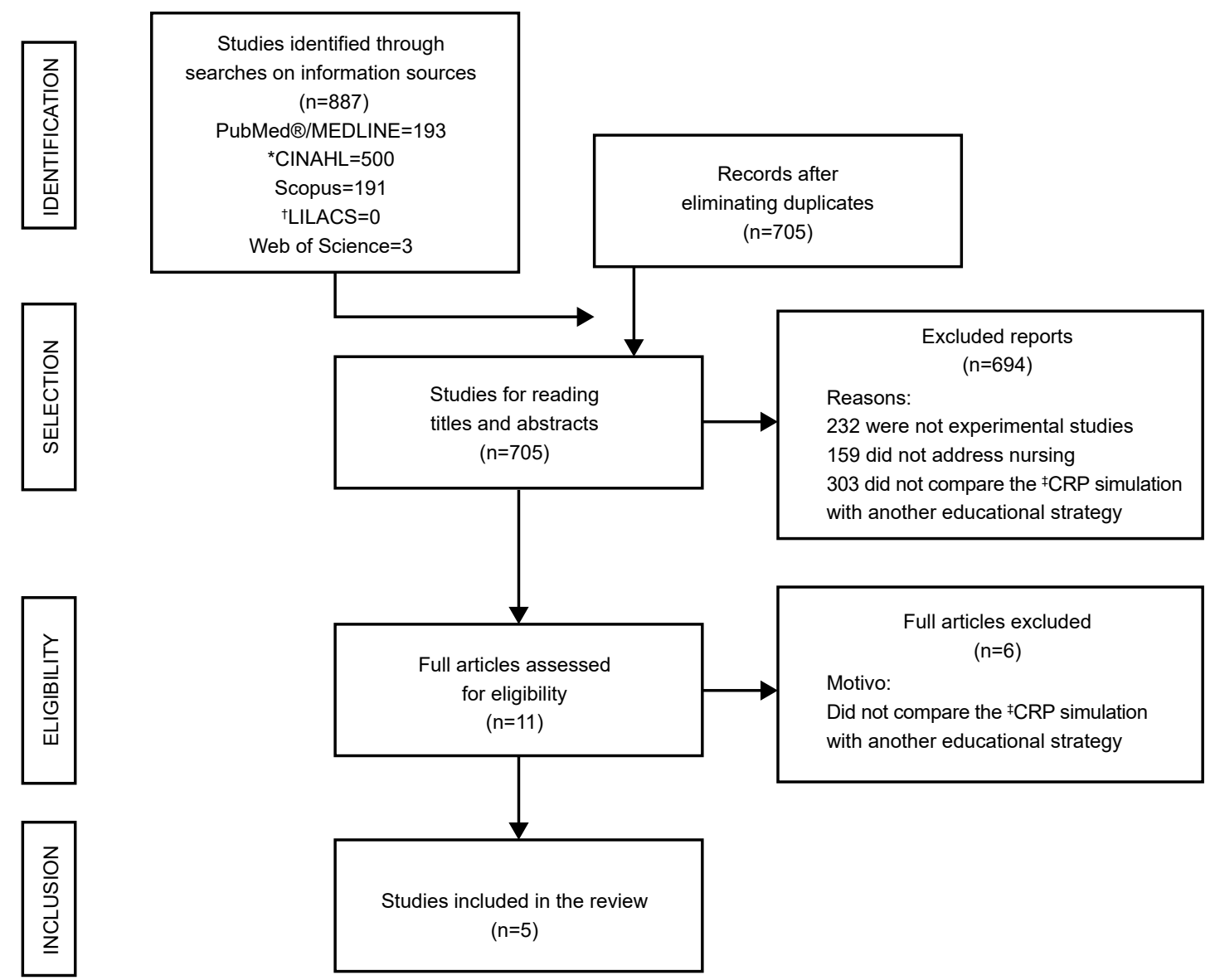

Source: Moher, et al.(13)

${ }^{*}$ CINAHL $=$ Cumulative Index to Nursing and Allied Health Literature; ${ }^{+}$LILACS $=$Latin American and Caribbean Literature in Health Sciences; ${ }^{*}$ CPR $=$ Cardiopulmonary resuscitation

Figure 1 - Flowchart of the identification, selection and inclusion process of studies adapted from the Preferred Reporting Items for Systematic Review and Meta-Analyzes (PRISMA). Despite the adoption of the instrument for critical evaluation of the studies from Joanna Briggs Institute, a protocol was not registered for this systematic review ${ }^{1}$. Ribeirão Preto, SP, Brazil, 2019

${ }^{1}$ It is noteworthy that, despite the adoption of the instrument for critical evaluation of the studies from Joanna Briggs Institute, a protocol was not registered for this systematic review. Own financing was obtained and there were no conflicts of interest. 


\section{Results}

The selection and inclusion of the studies in this research is shown in Figure 1, following the recommendations of the Preferred Reporting Items for Systematic Review and Meta-Analyzes-PRISMA ${ }^{(13)}$

Figure 2 shows the critical evaluation of the methodological quality of quasi-experimental studies, according to the evaluation instrument from Joanna Briggs Institute ${ }^{(19)}$.

Figure 3 shows the critical evaluation of the methodological quality of experimental studies, according to Joanna Briggs Institute evaluation instrument ${ }^{(19)}$.

The quasi-experimental studies included in this review met most of the quality assessment requirements indicated by the instrument of Joanna Briggs Institute, being considered of good quality. Only the criterion that addresses the use of multiple measurements of results in pre- and post-intervention/exposure over time has not been met in two studies ${ }^{(23-24)}$.

As for experimental studies, despite the fact that most criteria indicated for quality assessment have been met, there was a significant methodological weakness regarding the blinding of the researcher, participants, those responsible for providing treatment and results evaluators regarding the allocation of treatment.

MERSQI was also used to assess the methodological quality of the studies included in the sample, shown in Figure 4.

\begin{tabular}{|c|c|c|c|}
\hline Questions & Bruce, et al. ${ }^{(22)}$ & Ackermann ${ }^{(23)}$ & Akhu-Zaheya, et al. ${ }^{(24)}$ \\
\hline $\begin{array}{l}\text { 1. Is it clear in the study what the "cause" and "effect" are, that is, is there no confusion } \\
\text { which variable comes first? }\end{array}$ & Yes & Yes & Yes \\
\hline 2. Do the participants included in the groups have similar characteristics for comparison? & Yes & Yes & Yes \\
\hline $\begin{array}{l}\text { 3. Did the participants included in the groups receive similar treatment in the intervention } \\
\text { of interest? }\end{array}$ & Yes & Yes & Yes \\
\hline 4. Was there a control group? & Yes & Yes & Yes \\
\hline $\begin{array}{l}\text { 5. Were there multiple measurements of the pre- and post-intervention/exposure } \\
\text { outcome over time? }\end{array}$ & Yes & No & No \\
\hline $\begin{array}{l}\text { 6. Was the follow-up complete and, if not, were the differences between the groups } \\
\text { properly described and analyzed? }\end{array}$ & Yes & Yes & Yes \\
\hline 7. Were the participants' results, in any comparisons, measured in the same way? & Yes & Yes & Yes \\
\hline 8. Were results measured reliably? & Yes & Yes & Yes \\
\hline 9. Were appropriate statistical analyzes used? & Yes & Yes & Yes \\
\hline
\end{tabular}

Figure 2 - Evaluation of quasi-experimental studies included in the review, according to Joanna Briggs Institute methodological quality assessment instrument. Ribeirão Preto, SP, Brazil, 2019

\begin{tabular}{|c|c|c|}
\hline Questions & Aqel, et al. ${ }^{(25)}$ & Tawalbeh, et al. ${ }^{(26)}$ \\
\hline 1. Was the randomization used to allocate participants to treatment groups? & Yes & Yes \\
\hline 2. Was the researcher responsible for allocation to the treatment groups blinded? & It is not clear & It is not clear \\
\hline 3. Were the treatment groups similar? & Yes & Yes \\
\hline 4. Were the participants blinded in allocating treatment? & It is not clear & It is not clear \\
\hline 5. Were those responsible for providing treatment blinded? & It is not clear & It is not clear \\
\hline 6. Were the outcome assessors blinded regarding the allocation of treatment? & It is not clear & It is not clear \\
\hline 7. Were the treatment groups treated in the same way as the intervention of interest? & Yes & Yes \\
\hline $\begin{array}{l}\text { 8. Was the follow-up completed and, if not, were the differences between the groups in terms of follow-up } \\
\text { properly described and analyzed? }\end{array}$ & Yes & Yes \\
\hline 9. Were the participants analyzed in the groups to which they were allocated? & Yes & Yes \\
\hline 10. Were the results measured in the same way for treatment groups? & Yes & Yes \\
\hline 11. Were the results measured reliably? & Yes & Yes \\
\hline 12. Was appropriate statistical analysis used? & Yes & Yes \\
\hline $\begin{array}{l}\text { 13. Was the study design appropriate, and was there any deviation from the standard } \mathrm{RCT}^{*} \text { design in } \\
\text { conducting and analyzing? }\end{array}$ & Yes & Yes \\
\hline
\end{tabular}

$*$ RCT $=$ Randomized clinical trial

Figure 3 - Evaluation of the methodological quality of experimental studies included in the review, according to Joanna Briggs Institute critical evaluation instrument. Ribeirão Preto, SP, Brazil, 2019 
Through the use of MERSQI, it is possible to state that the studies included in the sample of this review had moderate methodological quality $(10<\mathrm{n}<15)$, with an average score of 12.5 points, a minimum value of 11 and a maximum value of 14.5 points. The criteria responsible for conferring methodological weakness were the execution of the studies in a single center/ institution and the lack of clarification as to the validity of the assessment instruments highlighted by these manuscripts.

The articles included in the review are summarized in Figure 5. All of them were international publications. The authors identified that clinical simulation was an effective teaching and learning strategy to develop clinical competence in nursing students for cardiopulmonary resuscitation, when compared to other teaching mechanisms.

\begin{tabular}{|c|c|c|c|c|c|}
\hline Domains & Bruce, et al. ${ }^{(22)}$ & Ackermannn ${ }^{(23)}$ & Akhu-Zaheya, et al. ${ }^{(24)}$ & Aqel, et al. ${ }^{(25)}$ & Tawalbeh, et al. ${ }^{(26)}$ \\
\hline Study design & $\begin{array}{l}\text { Non-randomized: } 2 \\
\text { points }\end{array}$ & $\begin{array}{l}\text { Non-randomized: } 2 \\
\text { points }\end{array}$ & $\begin{array}{l}\text { Non-randomized: } 2 \\
\text { points }\end{array}$ & $\begin{array}{l}\text { Randomized study: } \\
3 \text { points }\end{array}$ & $\begin{array}{l}\text { Randomized study: } 3 \\
\text { points }\end{array}$ \\
\hline $\begin{array}{l}\text { Sample (number } \\
\text { of centers where } \\
\text { the study was } \\
\text { conducted and } \\
\text { response rate) }\end{array}$ & $\begin{array}{l}\text { A single institution: } 0.5 \\
\text { point } \\
50 \%-74 \% \text { response rate: } \\
1 \text { point }\end{array}$ & $\begin{array}{l}\text { A single institution: } \\
0.5 \text { point } \\
>75 \% \text { response rate: } \\
1.5 \text { point }\end{array}$ & $\begin{array}{l}\text { A single institution: } 0.5 \\
\text { point } \\
50 \%-74 \% \text { response rate: } \\
1 \text { point }\end{array}$ & $\begin{array}{l}\text { A single institution: } \\
0.5 \text { point } \\
>75 \% \text { response rate: } \\
1.5 \text { point }\end{array}$ & $\begin{array}{l}\text { A single institution: } 0.5 \\
\text { point } \\
>75 \% \text { response rate: } \\
1.5 \text { point }\end{array}$ \\
\hline $\begin{array}{l}\text { Data type/ } \\
\text { evaluation }\end{array}$ & $\begin{array}{l}\text { Subjective evaluation: } \\
1 \text { point } \\
\text { Objective evaluation: } 2.0\end{array}$ & $\begin{array}{l}\text { Objective evaluation: } \\
2.0 \text { points }\end{array}$ & $\begin{array}{l}\text { Objective evaluation: } 2.0 \\
\text { points }\end{array}$ & $\begin{array}{l}\text { Objective evaluation: } \\
2.0 \text { points }\end{array}$ & $\begin{array}{l}\text { Objective evaluation: } \\
2.0 \text { points }\end{array}$ \\
\hline $\begin{array}{l}\text { Validity of the } \\
\text { evaluation } \\
\text { instrument }\end{array}$ & $\begin{array}{l}\text { Internal structure, } \\
\text { content, relations } \\
\text { with other unreported } \\
\text { variables: } 0 \text { point }\end{array}$ & $\begin{array}{l}\text { Internal structure and } \\
\text { reported content: } 1 \\
\text { point } \\
\text { Relations with other } \\
\text { unreported variables:0 }\end{array}$ & $\begin{array}{l}\text { Internal structure and } \\
\text { reported content: } 1 \text { point } \\
\text { Relations with other } \\
\text { unreported variables:0 }\end{array}$ & $\begin{array}{l}\text { Internal structure, } \\
\text { content, relations } \\
\text { with other unreported } \\
\text { variables: } 0 \text { point }\end{array}$ & $\begin{array}{l}\text { Internal structure and } \\
\text { reported content: } 1 \\
\text { point } \\
\text { Relations with other } \\
\text { unreported variables:0 }\end{array}$ \\
\hline Data analysis & $\begin{array}{l}\text { Appropriate for study } \\
\text { design: } 1 \text { point } \\
\text { In addition to the } \\
\text { descriptive analysis: } \\
2 \text { points }\end{array}$ & $\begin{array}{l}\text { Appropriate for study } \\
\text { design: } \\
1 \text { point } \\
\text { In addition to the } \\
\text { descriptive analysis: } \\
2 \text { points }\end{array}$ & $\begin{array}{l}\text { Appropriate for study } \\
\text { design: } \\
1 \text { point } \\
\text { In addition to the } \\
\text { descriptive analysis: } \\
2 \text { points }\end{array}$ & $\begin{array}{l}\text { Appropriate for study } \\
\text { design: } \\
1 \text { point } \\
\text { In addition to the } \\
\text { descriptive analysis: } \\
2 \text { points } \\
\end{array}$ & $\begin{array}{l}\text { Appropriate for study } \\
\text { design: } \\
1 \text { point } \\
\text { In addition to the } \\
\text { descriptive analysis: } \\
2 \text { points } \\
\end{array}$ \\
\hline Results & $\begin{array}{l}\text { Knowledge and skills: } 1.5 \\
\text { points } \\
\text { Satisfaction, attitudes, } \\
\text { perceptions, opinions, } \\
\text { general facts and } \\
\text { confidence: } 1 \text { point } \\
\end{array}$ & $\begin{array}{l}\text { Knowledge and skills: } \\
1.5 \text { points }\end{array}$ & $\begin{array}{l}\text { Knowledge and skills: } \\
1.5 \text { points } \\
\text { Satisfaction, attitudes, } \\
\text { perceptions and } \\
\text { confidence: } 1 \text { point }\end{array}$ & $\begin{array}{l}\text { Knowledge and } \\
\text { skills: } 1.5 \text { points }\end{array}$ & $\begin{array}{l}\text { Knowledge and skills: } \\
1.5 \text { points } \\
\text { Satisfaction, attitudes, } \\
\text { perceptions and } \\
\text { confidence: } 1 \text { point }\end{array}$ \\
\hline Total score & 11.0 & 12.5 & 13 & 11.5 & 14.5 \\
\hline
\end{tabular}

Figure 4 - Evaluation of the methodological quality of the studies, according to Medical Education Research Study Quality Instrument. Ribeirão Preto, SP, Brazil, 2019

\begin{tabular}{|c|c|c|c|c|}
\hline $\begin{array}{l}\text { Author, year and } \\
\text { country }\end{array}$ & Objectives & Method & Results/conclusion & $\begin{array}{c}\text { Evidence } \\
\text { level }\end{array}$ \\
\hline $\begin{array}{l}\text { Bruce, et al. } .^{(22)} \\
\text { 2009, United States } \\
\text { of America }\end{array}$ & $\begin{array}{l}\text { To compare the effectiveness } \\
\text { of clinical laboratory } \\
\text { simulation and a virtual } \\
\text { computer game, regarding } \\
\text { the development of } \\
\text { competence for CPR* in } \\
\text { nursing students } \\
\end{array}$ & $\begin{array}{l}\text { Quasi-experiment. Undergraduate } \\
\text { nursing course at an American } \\
\text { university. The control group had } \\
\text { clinical simulation on-site; the } \\
\text { experimental group had a virtual } \\
\text { computer game for CPR }\end{array}$ & $\begin{array}{l}\text { The scores for cognitive knowledge were } \\
\text { significant in both teaching strategies } \\
\text { ( } p=0.000) \text {, while post-simulation confidence } \\
\text { scores were not statistically significant } \\
(p=0.177) \text {. The use of virtual simulation in } \\
\text { CPR is effective, but on-site simulation is } \\
\text { necessary to develop confidence in students }\end{array}$ & 3 \\
\hline $\begin{array}{l}\text { Ackermann }{ }^{(23)} 2009, \\
\text { United States of } \\
\text { America }\end{array}$ & $\begin{array}{l}\text { To compare the effectiveness } \\
\text { of clinical CPR simulation } \\
\text { for nursing students with } \\
\text { a traditional CPR teaching } \\
\text { strategy }\end{array}$ & $\begin{array}{l}\text { Quasi-experiment. Undergraduate } \\
\text { nursing course (65 American } \\
\text { students). The experimental group } \\
\text { had classes, skills training and } \\
\text { clinical simulation in CPR; the } \\
\text { control group had classes and } \\
\text { skills training }\end{array}$ & $\begin{array}{l}\text { The experimental group proved to } \\
\text { be statistically more significant in the } \\
\text { development of clinical competence in CPR } \\
\text { when compared to the traditional strategy. } \\
\text { Teaching CPR through clinical simulation is } \\
\text { effective for nursing }\end{array}$ & 3 \\
\hline $\begin{array}{l}\text { Akhu-Zaheya, et } \\
\text { al. }{ }^{(24)}, 2013 \text {, Jordan }\end{array}$ & $\begin{array}{l}\text { To examine the effectiveness } \\
\text { of clinical simulation for } \\
\text { CPR regarding knowledge } \\
\text { acquisition, retention and } \\
\text { self-efficacy of Jordanian } \\
\text { nursing students }\end{array}$ & $\begin{array}{l}\text { Quasi-experiment. Undergraduate } \\
\text { nursing course in Jordan ( } 110 \\
\text { students). The experimental } \\
\text { group }(n=52) \text { had PowerPoint } \\
\text { classes, skills training and clinical } \\
\text { simulation, while the control group } \\
\text { ( } n=58 \text { ) had PowerPoint classes } \\
\text { and skills training }\end{array}$ & $\begin{array}{l}\text { The experimental group achieved higher } \\
\text { scores for knowledge acquired and } \\
\text { retained in CPR and greater perception of } \\
\text { self-efficacy. Nursing students should be } \\
\text { educated with more realistic technologies, } \\
\text { such as simulation }\end{array}$ & 3 \\
\hline
\end{tabular}




\begin{tabular}{|c|c|c|c|c|}
\hline $\begin{array}{l}\text { Author, year and } \\
\text { country }\end{array}$ & Objectives & Method & Results/conclusion & $\begin{array}{c}\text { Evidence } \\
\text { level }\end{array}$ \\
\hline $\begin{array}{l}\text { Aqel, et al. }{ }^{(25)}, 2014 \text {, } \\
\text { Jordan }\end{array}$ & $\begin{array}{l}\text { To examine the effectiveness } \\
\text { of clinical CPR simulation for } \\
\text { competence development } \\
\text { and retention in nursing } \\
\text { students }\end{array}$ & $\begin{array}{l}\text { Randomized experiment. } \\
\text { Undergraduate nursing course } \\
\text { in Jordan (90 students). } \\
\text { The experimental group had } \\
\text { PowerPoint classes and clinical } \\
\text { CPR simulation, and the control } \\
\text { group had PowerPoint classes and } \\
\text { CPR skills training }\end{array}$ & $\begin{array}{l}\text { Significant differences were identified in } \\
\text { favor of the experimental group in the } \\
\text { development of competence for CPR. } \\
\text { The results of this study favor the use of } \\
\text { simulation for nursing education }\end{array}$ & 2 \\
\hline $\begin{array}{l}\text { Tawalbeh, et al. }{ }^{(26)} \text {, } \\
2014 \text {, Jordan }\end{array}$ & $\begin{array}{l}\text { To examine the effect } \\
\text { of clinical simulation on } \\
\text { cognitive knowledge, } \\
\text { knowledge retention and } \\
\text { nursing students' confidence } \\
\text { in CPR }\end{array}$ & $\begin{array}{l}\text { Randomized experiment (100 } \\
\text { students). Undergraduate nursing } \\
\text { course in Jordan. The experimental } \\
\text { group ( } n=50 \text { ) had CPR simulation, } \\
\text { PowerPoint presentation and skills } \\
\text { training. The control group had } \\
\text { PowerPoint classes and CPR skills } \\
\text { training }\end{array}$ & $\begin{array}{l}\text { The experimental group had greater } \\
\text { knowledge about CPR and confidence, } \\
\text { compared to the control group. Simulation } \\
\text { is significantly more effective than traditional } \\
\text { training for teaching nursing students }\end{array}$ & 2 \\
\hline
\end{tabular}

*CPR $=$ Cardiopulmonary resuscitation

Figure 5 - Characterization of the studies that comprised the sample of this systematic review. Ribeirão Preto, SP, Brazil, 2019

\section{Discussion}

A total of three quasi-experimental studies ${ }^{(22-24)}$ and two experimental(25-26) were included in the sample of this review. Although all authors have pointed to clinical simulation as an effective strategy to develop clinical competence for cardiopulmonary resuscitation in nursing students, the scarcity of identified studies demonstrates the need for further scientific exploration in this area(9).

Most(22-23,25-26) studies have compared clinical simulation in CPR with traditional teaching and learning strategies for nursing, such as lecture with the support of PowerPoint presentations and the training of laboratory skills using a low fidelity manikin. They obtained statistically significant results for clinical simulation in CPR in view of other exposed methods, which can subsidize their use in nursing education ${ }^{(9,22-23)}$.

A randomized experimental study carried out with a total of 31 Chinese nurses, that compared the effectiveness of simulation to develop nursing competence with traditional teaching strategies corroborates this statements, highlighting statistically significant results for the increase of cognitive and psychomotor skills $(p=0.001)$, a reduction in stress levels $(p=0.011)$ and increased confidence $(p=0.026)^{(27)}$.

Other studies have also pointed out clinical simulation as an innovative pedagogical strategy for the development of cognitive, psychomotor and affective skills in nursing, affirming its effectiveness for the development of clinical competence ${ }^{(25,28-30)}$.

This review used two different instruments(19-20) to assess the methodological quality of the selected article sample. Joanna Briggs Institute instrument pointed out the good quality of quasi-experimental and experimental studies, but it highlighted the blinding criterion as an important methodological weakness in experimental studies.

The absence of the participant, personnel or statistician blinding, in a scientific study, can compromise the methodological quality by providing biased behavior of those involved and research bias, which affects the internal validity of the investigations and makes the effectiveness of the research uncertain. However, it is worth noting the existing difficulty to perform blinding in educational experiments, mainly due to the impossibility of guaranteeing the absence of exchange of information among the participants involved(19,31-36).

MERSQI, another instrument used in this study, is described as reliable because it provides accuracy in identifying the methodological quality of the articles(37). This assessment instrument identified a moderate level of quality in the researches that comprised the sample, highlighting as main weaknesses the execution of studies in a single center/institution and the lack of clarification of the validity of the instruments used.

This result is similar to a systematic review study on education based on simulation in nursing, which also used MERSQI and indicated moderate methodological quality for a sample of a total of 26 articles, in addition to the need for improvement in the preparation of educational intervention studies in nursing, mainly because they are performed in a single center and do not consider the previous validation of the instruments used(37).

Despite the fact that multicenter clinical trials are considered the gold standard in research, since they attend different communities and reduce the time of experimentation, they are generally expensive and complex studies, which makes its execution difficult and can justify the fact that most scientific publications on 
pedagogical interventions in nursing be carried out in a single center ${ }^{(38)}$.

On the other hand, the validation of instruments is a criterion of fundamental methodological quality, as it confers the reliability of the intended findings. The lack of clarification on this issue, in the studies that comprised the sample of this review, may compromise the reliability of the statistical conclusions of researches and justify its moderate methodological quality(39).

This study had two main limitations: the incipience of quasi-experimental and experimental articles on the effectiveness of simulation to develop clinical competence in CPR; and the difficulty to compare the results of the studies that made up the sample, in view of the approach to different evaluation instruments.

Based on the findings of this systematic review, it is possible to add scientific evidence capable of supporting the teaching and learning process of CPR in undergraduate nursing through clinical simulation, indicating its effectiveness, focusing on the methodological quality of studies, which is an important resource in view of the accelerated growth of information.

\section{Conclusion}

We identified a total of five studies that confirm the effectiveness of clinical simulation to develop competence in cardiopulmonary resuscitation for nursing, in view of other pedagogical strategies. Joanna Briggs Institute methodological assessment instrument demonstrated good quality of the included studies, and the Medical Education Research Study Quality Instrument showed moderate methodological quality.

This study contributes to teaching, research and nursing care, as it demonstrates the effectiveness of simulation as a teaching and learning strategy, indicating it as a pedagogical possibility to develop clinical competence in cardiopulmonary resuscitation.

\section{References}

1. Sanaie N, Vasli P, Sedighi L, Sadeghi B. Comparing the effect of lecture and Jigsaw teaching strategies on the nursing students' self-regulated learning and academic motivation: A quasiexperimental study. Nurse Educ Today. 2019 May;79:35-40. doi: https://doi. org/10.1016/j.nedt.2019.05.022

2. Wilson L, Mendes IA, Klopper H, Catrambone C, Al-Maaitah R, Norton ME, et al. Global health' and 'global nursing': proposed definitions from the global advisory panel on the future of nursing. J Adv Nurs. 2016 Jul;72(7):1529-40. doi: https://doi.org/10.1111/ jan. 12973
3. Jeffries PR, Rodgers $B$, Adamson K. NLN Jeffries Simulation Theory: Brief Narrative Description. Nurs Educ Perspect. [Internet]. 2015 Sep/Oct [cited Jul 18, 2019];36(5):292-3. Available from: https:// www.nursingcenter.com/journalarticle? Article_ ID $=3350601 \&$ Journal_ID $=3332683$ \&Issue_ID $=3350571$ 4. Berger C, Brinkrolf P, Ertmer C, Becker J, Friederichs $\mathrm{H}$, Wenk $\mathrm{M}$, et al. Combination of problem-based learning with high-fidelity simulation in CPR training improves short and long-term CPR skills: a randomised single blinded trial. BMC Med Educ. 2019 May;19(1):180. doi: https://doi.org/10.1186/s12909-019-1626-7

5. Nasr-Esfahani M, Yazdannik A, Mohamadiriz S. Development of nursing students' performance in advanced cardiopulmonary resuscitation through roleplaying learning model. J Educ Health Promot. 2019 Aug 30;8:151. doi:10.4103/jehp.jehp_125_18

6. O'Leary JR, Goumeniouk NL, Cormier AS, Potter DJ, Gilic F, Brennan EE. Competency in Acute Resuscitation Through Successive Simulation (CARTSS): a mentor based near-peer learning initiative Can. J Emerg Med. 2018 Nov;20(6):952-4. doi: https://doi.org/10.1017/ cem. 2018.28

7. Vesilea U, Basak T, Ayhan H, Cinar FI, Iyigun E, Tosun $\mathrm{N}$, et al. Integrating simulation based learning into nursing education programs: Hybrid simulation. Technol Health Care. 2018 Apr 23;26(2):263-70. doi: 10.3233/ THC-170853

8. Lee J, Cheng A, Angelski C, Allain D, Ali S. Highfidelity simulation in pediatric emergency medicine: a national survey of facilitator comfort and practice. Pediatr Emerg Care. 2015 Apr;31(4):260-5. doi: 10.1097/PEC.0000000000000396

9. Lejonqvist GB, Eriksson K, Meretoja R. Evaluating clinical competence during nursing education: $A$ comprehensive integrative literature review. Int J Nurs Pract. 2016 Apr;22(2):142-51. doi: https://doi. org/10.1111/ijn.12406

10. McRae ME, Chan A, Hulett R, Leea AJ, Coleman B. The effectiveness of and satisfaction with high-fidelity simulation to teach cardiac surgical resuscitation skills to nurses. Intens Crit Care Nurs. 2017 Jun;40:64-9. doi: 10.1016/j.iccn.2016.11.001

11. Roh YS, Lim EJ, Issenberg SB. Effects of an integrated simulation-based resuscitation skills training with clinical practicum on mastery learning and self-efficacy in nursing students. Collegian. 2016 Dec 31;23(1):53-9. doi: https://doi.org/10.1016/j.colegn.2014.10.002

12. Downar J, McNaughton N, Abdelhalim T, Wong $N$, Lapointe-Shaw L, Seccareccia D, et al. Standardized patient simulation versus didactic teaching alone for improving residents' communication skills when discussing goals of care and resuscitation: A randomized 
controlled trial. Palliat Med. 2016 Feb;31(2):130-9. doi: 10.1177/02692163166522782016

13. Moher D, Liberati A, Tetzlaff J, Altman DG; PRISMA Group. Preferred reporting items for systematic reviews and metaanalyses: the PRISMA statement. PLoS Med. 2009 Jul;6(7):e1000097. doi: https://doi.org/10.1371/ journal.pmed. 1000097

14. Clarke M. The Cochrane Collaboration and systematic reviews. Br J Surg. 2007 Apr;94(4):391-2. doi: 10.1002/bjs.5812

15. Santos CM, Pimenta CA, Nobre MR. The PICO strategy for the research question construction and evidence search. Rev Latino-Am Enfermagem. 2007 May-Jun;15(3):508-51. doi: http://dx.doi.org/10.1590/ S0104-11692007000300023

16. Ouzzani M, Hammady H, Fedorowicz Z, Elmagarmid A. Rayyan - a web and mobile app for systematic reviews. Syst Rev. 2016;5(1):210. doi: 10.1186/s13643-0160384-4

17. Ursi ES, Galvão CM. Perioperative prevention of skin injury: an integrative literature review. Rev LatinoAm Enfermagem. [Internet]. 2006 Jan-Feb [cited Nov 4, 2019];14(1):124-31. Available from: http://www. scielo.br/pdf/rlae/v14n1/v14n1a17

18. Melnyk BM, Fineout-Overholt E. Evidence-based practice in nursing \& healthcare: a guide to best practice.

2. ed. Philadelphia: Wolters Kluwer Health/Lippincott Williams \& Wilkins; 2011.

19. Joanna Briggs Institute. JBI Reviewer's Manual. [Internet]. The Joanna Briggs Institute; 2017 [cited Nov 4, 2019]. Available from: https://reviewersmanual. joannabriggs.org/

20. Reed DA, Beckman TJ, Wright SM, Levine RB, Kern $D E$, Cook DA. Predictive Validity Evidence for Medical Education Research Study Quality Instrument Scores: Quality of Submissions to JGIM's Medical Education Special Issue. J Gen Intern Med. 2008 Jul;23(7):903-7. doi: https://doi.org/10.1007/s11606-008-0664-3 21. Fontaine G, Cossette S, Maheu-Cadotte MA, Mailhot $T$, Heppell S, Roussy C, et al. Behavior change counseling training programs for nurses and nursing students: A systematic descriptive review. Nurse Educ Today. 2019 Nov;82:37-50. https://doi.org/10.1016/j. nedt.2019.08.007

22. Aqel AA, Ahmad MM. High-fidelity simulation effects on CPR knowledge, skills, acquisition, and retention in nursing students. Worldviews Evid Based Nurs. 2014 Dec;11(6):394-400. doi: 10.1111/wvn.12063

23. Tawalbeh LI, Tubaishat A. Effect of simulation on knowledge of advanced cardiac life support, knowledge retention, and confidence of nursing students in Jordan. J Nurs Educ. 2014 Jan;53(1):38-44. doi: 10.3928/01484834-20131218-01
24. Bruce AS, Scherer YK, Curran CC, Urschel DM, Erdley S, Ball LS. A collaborative exercise between graduate and undergraduate nursing students using a computer-assisted simulator in a mock cardiac arrest. Nurs Educ Perspect. [Internet]. 2009 Jan-Feb [cited Jan 13, 2019];30(1):22-7. Available from: https://www. ncbi.nlm.nih.gov/pubmed/19331035

25. Ackermann AD. Investigation of Learning Outcomes for the Acquisition and Retention of CPR Knowledge and Skills Learned with the Use of High-Fidelity Simulation. Clin Simul Nurs. 2009 Nov-Dec;5(6):e213-e222. doi: 10.1016/j.ecns.2009.05.002

26. Akhu-Zaheya LM, Gharaibeh MK, Alostaz ZM. Effectiveness of Simulation on Knowledge Acquisition, Knowledge Retention, and Self-Efficacy of Nursing Students in Jordan. Clin Simul Nurs. 2013 Sep;9(9):e335-e342. doi: https://doi.org/10.1016/j. ecns.2012.05.001

27. Chen SH, Chen SH, Lee SC, Chang Y, Yeh KY. Impact of interactive situated and simulated teaching program on novice nursing practitioners' clinical competence, confidence, and stress. Nurse Educ Today. 2017 Aug;55:11-6. doi: 10.1016/j.nedt.2017.04.025

28. Weeks KW, Coben D, O'Neill D, Jones A, Weeks $A$, Brown $M$, et al. Developing and integrating nursing competence through authentic technologyenhanced clinical simulation education: Pedagogies for reconceptualising the theory-practice gap. Nurse Educ Pract. 2019 May;37:29-38. doi: https://doi. org/10.1016/j.nepr.2019.04.010

29. Brown Tyo M, McCurry MK. An Integrative Review of Clinical Reasoning Teaching Strategies and Outcome Evaluation in Nursing Education. Nurs Educ Perspect. 2019 Jan-Feb;40(1):11-7. doi: 10.1097/01. NEP.0000000000000375

30. Everett-Thomas R, Turnbull-Horton V, Valdes B, Valdes GR, Rosen LF, Birnbach DJ. The influence of highfidelity simulation on first responder's retention of CPR knowledge. Appl Nurs Res. 2016 May;30:94-7. doi: https://doi.org/10.1016/j.apnr.2015.11.005

31. Liaw SY, Carpio GA, Lau Y, Tan SC, Lim WS, Goh PS. Multiuser virtual worlds in healthcare education: $A$ systematic review. Nurse Educ Today. 2018 Jun;65:13649. doi: https://doi.org/10.1016/j.nedt.2018.01.006

32. Langford CA, Cuthbertson D, Ytterberg SR, Khalidi N, Monach PA. A Randomized, Double-Blind Trial of Abatacept (CTLA-4Ig) for the Treatment of Giant Cell Arteritis. Arthritis Rheumatol. 2017 Apr;69(4);837-45. doi: 10.1002 /art.40044

33. Vasconcelos BC. Blinding in scientific research. Rev Cir Traumatol Buco-Maxilo-Fac. [Internet]. 2016 JanMar [cited Jan 13, 2019];16:5-5. Available from: http:// 
revodonto.bvsalud.org/scielo.php?script=sci_arttext\&pi $\mathrm{d}=$ S1808-52102016000100001

34. Barnett JB, Dao MC, Hamer DH, Kandel R, Brandeis $G, W u$, et al. Effect of zinc supplementation on serum zinc concentration and $\mathrm{T}$ cell proliferation in nursing home elderly: a randomized, double-blind, placebocontrolled trial. Am J Clin Nutr. 2016 Mar;103(3):94251. https://doi.org/10.3945/ajcn.115.115188

35. Saunders $H$, Vehviläinen-Julkunen $K$, Stevens KR. Effectiveness of an education intervention to strengthen nurses' readiness for evidence-based practice: A singleblind randomized controlled study. Appl Nurs Res. 2016 Aug;31:175-85. doi: 10.1016/j.apnr.2016.03.004 36. Rajab AM, Hamza A, Aldairi RK, Alaloush MM, Saquib J, Saquib N. Systematic review on the quality of randomized controlled trials from Saudi Arabia. Contemp Clin Trials Commun. 2019 Dec;16. doi: https://doi. org/10.1016/j.conctc. 2019.100441

37. Cant RP, Levett-Jones T, James A. Do Simulation Studies Measure up? A Simulation Study Quality Review. Clin Simul Nurs. 2018 Aug;21:23-39. doi https://doi. org/10.1016/j.ecns.2018.06.002

38. Florentino AO, Franca FT, Silveira GC, D'Amico GC, Henriques VS. The importance of ethics during the development of research and clinical trials. Revi Intersaúde. [Internet]. 2019 Sep 4 [cited Jan 13, 2019];1(1):91-111. Available from: http://revista. fundacaojau.edu.br:8078/journal/index.php/revista_ intersaude/article/view/113/69

39. Cunha CM, Almeida Neto OP, Stackfleth R. Main psychometric evaluation methods of the validity of measuring instruments. Rev Aten Saúde. 2016 JanMar;14(47):75-83. doi: 10.13037/rbcs.vol14n47.3391
Corresponding author:

Juliana da Silva Garcia Nascimento

E-mail: mestradounesp28@yahoo.com.br

(iD) https://orcid.org/0000-0003-1118-2738
Copyright $\odot \mathbf{2 0 2 0}$ Revista Latino-Americana de Enfermagem This is an Open Access article distributed under the terms of the Creative Commons (CC BY).

This license lets others distribute, remix, tweak, and build upon your work, even commercially, as long as they credit you for the original creation. This is the most accommodating of licenses offered. Recommended for maximum dissemination and use of licensed materials. 